\title{
Advancing psychosocial care in cancer patients [version 1;
}

\section{peer review: 3 approved]}

\section{Luigi Grassi (D1,2, David Spiegel3, Michelle Riba4,5}

\author{
${ }^{1}$ University Hospital Psychiatric Unit, Integrated Department of Mental Health and Addictive Behavior, S. Anna University Hospital \\ and Health Trust, Ferrara, Italy \\ ${ }^{2}$ Institute of Psychiatry, Department of Biomedical and Specialty Surgical Sciences, University of Ferrara, Ferrara, Italy \\ ${ }^{3}$ Department of Psychiatry \& Behavioral Sciences, Stanford University School of Medicine, Stanford, California, USA \\ ${ }^{4}$ University of Michigan Comprehensive Cancer Center, Ann Arbor, Michigan, USA \\ ${ }^{5}$ Department of Psychiatry, University of Michigan, Ann Arbor, Michigan, USA
}

V1 First published: 04 Dec 2017, 6(F1000 Faculty Rev):2083

https://doi.org/10.12688/f1000research.11902.1

Latest published: 04 Dec 2017, 6(F1000 Faculty Rev):2083

https://doi.org/10.12688/f1000research.11902.1

\section{Abstract}

Cancer is a devastating disease causing significant psychological problems among patients and their families. In the past few decades, there have been growing implementation and dissemination of screening methods for the psychological consequences of cancer, including distress, depression, anxiety, post-traumatic stress, and demoralisation. Also, guidelines for the management of psychological distress have been developed and endorsed by a number of scientific cancer associations. This review examines some of the most significant related issues, also focusing on recent advances in psychosocial and psychopharmacological interventions as a part of a mandatory, integrated, and comprehensive approach to cancer care.

\section{Keywords}

psycho-oncology, cancer, psychological screening assessment, distress, psychopathology, psychotherapy

\section{Open Peer Review}

Approval Status

1

2

3

version 1

04 Dec 2017

Faculty Reviews are review articles written by the prestigious Members of Faculty Opinions. The articles are commissioned and peer reviewed before publication to ensure that the final, published version is comprehensive and accessible. The reviewers who approved the final version are listed with their names and affiliations.

\section{Anja Mehnert-Theuerkauf, University Medical Center Leipzig, Leipzig, Germany \\ 2. Linda E. Carlson, University of Calgary, Calgary, Canada}

\section{Kristine Donovan, Moffitt Cancer Center,}

Tampa, USA

Any comments on the article can be found at the end of the article. 
Corresponding author: Luigi Grassi (luigi.grassi@unife.it)

Author roles: Grassi L: Conceptualization, Methodology, Writing - Original Draft Preparation; Spiegel D: Writing - Review \& Editing; Riba M: Writing - Review \& Editing

Competing interests: No competing interests were disclosed.

Grant information: Luigi Grassi acknowledges the support of the University of Ferrara research grant FAR-2016. David Spiegel acknowledges the support of NCI U01 CA 197282 and the Stanford Cancer Institute, an NCI-designated Comprehensive Cancer Center. The funders had no role in study design, data collection and analysis, decision to publish, or preparation of the manuscript.

Copyright: $\odot 2017$ Grassi L et al. This is an open access article distributed under the terms of the Creative Commons Attribution License, which permits unrestricted use, distribution, and reproduction in any medium, provided the original work is properly cited.

How to cite this article: Grassi L, Spiegel D and Riba M. Advancing psychosocial care in cancer patients [version 1; peer review: 3 approved] F1000Research 2017, 6(F1000 Faculty Rev):2083 https://doi.org/10.12688/f1000research.11902.1

First published: 04 Dec 2017, 6(F1000 Faculty Rev):2083 https://doi.org/10.12688/f1000research.11902.1 


\section{Introduction}

World Health Organization (WHO) projections estimate the incidence of cancer to increase exponentially by the year 2030, with the annual number of new cases rising from 14.1 million in 2012 to 21.6 million in 2030 and deaths due to cancer rising from 8.8 million worldwide in 2015 to more than 12 million in $2030^{1}$. At the same time, earlier diagnoses and improvement in cancer therapies have also led to an increase in survival that includes more than 300 million cancer survivors around the world. A broad implication of these figures involves the psychosocial impact of the disease, including emotional consequences, supportive care needs, and quality of life of cancer patients and their families. It is a fact that cancer is not only a series of very different diseases needing complex and multidisciplinary treatment but also a very stressful event with significant psychosocial implications related to physical, emotional, spiritual, and interpersonal dimensions. All aspects of life, including the parameters of time (e.g. the past, the present, and the future), space (e.g. one's own individual space, one's own home, and one's own world context), and existence (e.g. confrontation with mortality) are altered by the diagnosis and treatment, recovery and long-survivorship, recurrence, or transition to palliative and end-of-life care.

In this review, we examine and summarise the recent data relative to the psychosocial consequences of cancer and the most significant policies regarding screening, assessment, and psychological treatment of emotional distress and concomitant psychosocial disorders among cancer patients.

\section{Psychological aspects of cancer}

Recent data have examined the psychological consequences of cancer, showing that, at the physical level, cancer and cancer treatment have evident repercussions for body image, with differences between "visible cancers" (e.g. breast cancer and head and neck cancers) and "less-visible cancers" (e.g. leukaemia and lung cancer). The type of therapy, including surgery, chemotherapy, radiotherapy, immune therapy, and hormone therapy, also has important effects because of possible physical changes that may result (e.g. amputations, stomas, and hair loss) and symptoms (e.g. pain, nausea and vomiting, and fatigue $)^{2}$.

Declines in performance status and functional activity, problems in carrying on one's own daily activities, poor concentration, memory impairment, or altered sexuality are important in influencing the psychological response of cancer patients ${ }^{3}$. The loss of certainty, the instability of one's own emotional status (e.g. fears, anxiety, worries, and sadness), the need to depend on others, the reduction of self-esteem, the change of perspective about the future, and the threat of possible death are some examples of the multitude of emotional effects and experiences cancer patients have to deal with during the trajectory of the illness. Spiritually, the whole set of personal values, the meaning given to one's own life and existence, and the change in perception of time and being are important concomitants of cancer. The social and interpersonal dimension is also touched by cancer and its treatment. The sense of belonging ("to be with") and communicating ("to have commonality with someone") in the family, in the microcosm of close relationships, and in the macrocosm of broader work, social, and community involvement is also threatened or impaired by cancer. Feelings of loneliness and abandonment, problems in returning to work, marginalisation, or even stigmatisation are common issues that cancer patients report ${ }^{2,3}$.

All of these aspects may be evident in different phases of the trajectory of illness from diagnosis to survivorship or palliative care and the course of cancer (e.g. remission, recurrence, progression, and end of life). Cancer patients may adopt several styles of emotional, cognitive, and behavioural response to the disease. It has been shown that some styles, such as a fighting spirit (i.e. the tendency to confront and actively face the illness), seem to favour adjustment to illness, while others, such as hopelessness (i.e. the tendency to adopt a pessimistic attitude to the illness), anxious preoccupation (i.e. the tendency to constantly perceive the impact of illness in one's own life), and denial, tend to be associated with poorer adjustment to illness and a higher risk of distress ${ }^{4}$. Distress, in fact, is quite common in cancer patients and has been particularly studied over the last 20 years. It has been very broadly defined as "a multifactorial, unpleasant, emotional experience of a psychological (cognitive, behavioural, emotional), social and/or spiritual nature that may interfere with the ability to cope effectively with cancer, its physical symptoms and its treatment and that extends along a continuum, ranging from common normal feelings of vulnerability, sadness and fears to problems that can become disabling, such as depression, anxiety, panic, social isolation and existential and spiritual crisis" ${ }^{5}$. Distress has also been termed the "Sixth Vital Sign" in cancer care ${ }^{6,7}$, and routine assessment and treatment of distress has been mandated by numerous regulatory bodies, including the International PsychoOncology Society (IPOS) Standard on Quality Cancer Care, stating that quality cancer care must integrate the psychosocial domain into routine care and that emotional distress should be measured as the sixth vital sign ${ }^{8}$.

Many cancer patients have problems in adjusting during the illness trajectory, with "normal" psychological responses (e.g. sadness and preoccupation) shifting to more clinically significant states characterised by symptoms of anxiety or depressive disorders or other psychopathological conditions. Several factors have been enumerated as increasing the risk for the onset of psychopathological conditions, such as previous history of psychiatric disorders or trauma, inadequate and poor social support, uncontrolled symptoms, and female gender?.

A psychopathological condition can be diagnosed, according to recent data in the literature, in $25-30 \%$ of patients by using the usual nosological systems of psychiatric classification (e.g. the International Classification of Disease, tenth edition [ICD-10] of WHO or the Diagnostic and Statistical Manual of Mental Disorders, Fifth Edition [DSM-5] of the American Psychiatric Association $)^{10}$. The most common diagnoses include stressrelated and adjustment disorders ${ }^{11}$, depressive spectrum disorders (including major depression and minor depression) $)^{12,13}$, anxiety disorders ${ }^{14}$, and sexual disorders (e.g. loss of libido and anorgasmia) ${ }^{15}$. Other psychological maladjustment conditions, such as demoralisation syndrome, health anxiety, and somatic 
symptom disorders, have also been underlined as clinically significant areas to be taken into account in cancer care ${ }^{16-19}$. Different phases of the illness trajectory can trigger emotional distress and the onset of psychological disorders, as reported in the US National Comprehensive Cancer Network (NCCN) distress management guidelines (Table 1) .

Given the high number of cancer patients surviving their disease, survivorship has recently occupied more attention of both researchers and clinicians interested in psychosocial oncology, with data indicating that the creation and implementation of optimal methods for promoting the health and wellbeing of posttreatment survivors are critical for complete cancer care. The risk is that, since the disease has been treated and the patient recovered, psychological problems are not considered significant anymore. For example, one study indicated that only $40.2 \%$ of survivors reported having had a discussion with their clinicians about how cancer may have affected their emotions or relationships and that more than $90 \%$ of the barriers to the use of professional counselling or support groups identified by survivors involved lack of knowledge about, or perceived unavailability of, services ${ }^{20}$. Thus, it is extremely important that clinicians monitor supportive care needs in patients surviving cancer, especially for those reporting fear of cancer recurrence, and anxiety, important issues present in cancer survivors ${ }^{21}$. It is true that, in general, the rate of psychological morbidity tends to be lower in survivors rather than patients with active or recurrent disease ${ }^{22}$. However, a series of problems can be present in this population (e.g. fear of cancer recurrence, possible long-term mental and physical side effects, economic burdens, and distress ${ }^{23,24}$, including particularly those who received a cancer diagnosis during adolescence or young adulthood ${ }^{25}$. With respect to this, Aaronson et al. ${ }^{26}$ have underscored a series of psychosocial issues to be taken into account in a person-centered approach to survivors of cancer (Table 2).

\section{Consequences of psychological distress and disorders}

Distress symptoms and psychological disorders secondary to cancer have also been shown to have significant negative consequences for both the patient and the family. Maladaptive coping and abnormal illness behaviour have been associated with psychiatric conditions, with negative effects on adherence to treatment,

Table 1. Some of the phases of cancer presenting risk for the onset of psychological distress (from National Comprehensive Cancer Network).

- Finding a suspicious symptom

- Being informed about the diagnosis

- Awaiting treatment

- Change or end of treatment

- Discharge from hospital

- Surviving cancer

- Failure of treatment

- Recurrence or progression of disease

- Advanced phase of illness

- Approaching the end of life
Table 2. Suggestions about what should be done for survivors of cancer.

- Symptoms not viewed in isolation but rather as part of a cluster of interrelated problems

- Psychosocial interventions to be evidence-based and where possible tailored to the needs of the individual cancer survivor

- More effort devoted to disseminating and implementing interventions in practice and to evaluating their costeffectiveness

- Greater attention paid to the needs of vulnerable and high-risk populations of survivors, including the socioeconomically disadvantaged and the elderly

Suggestions collated from Aaronson et al.26

health behaviour, and quality of life ${ }^{3}$. Also, an increased length of stay in the hospital and/or an increased time in rehabilitation have been found to be more common among patients showing psychiatric symptoms, especially depression, than those with normal adjustment to illness ${ }^{11}$. Data exist about the reduced response to chemotherapy among depressed breast cancer patients, indicating a possible relationship between psychological disorders and higher risk of recurrence and decreased overall survival $^{27}$. An increased risk of suicide has also been associated with psychological disorders in cancer ${ }^{28}$.

Emotional problems such as depression and anxiety, may also reverberate within the family, increasing emotional distress among the patient's care-givers and, in the case of a patient's death, risking a greater chance of complicated or traumatic grief among relatives.

In spite of these findings and their implications for clinical care, psychosocial problems in cancer are still minimised and underestimated. Cancer care professionals tend to confuse clinical depression (feeling hopeless, helpless, worthless, or suicidal) or anxiety disorders (phobic avoidance, agitation, constant worry) with normal sadness and preoccupation, with the mistaken belief that "it is normal to feel sad or anxious because of cancer". The result is that the psychological issues experienced by $30-40 \%$ of cancer patients are not identified by the clinician, so these patients are not referred to the correct psychiatric or psycho-oncology service for specialised evaluation and therapy ${ }^{29}$. However, without better appreciation for and shifts in social attitude towards mental health applied to medicine, including oncology, cancer patients with maladjustment disorders may not receive or accept referral to psycho-oncology services to be assessed and treated for these psychological problems.

\section{Evaluation and management of psychological and psychosocial dimensions in cancer}

In fact, screening and assessment of the emotional problems and concerns of both the patient and the family should in fact be part of every clinical intervention by oncologists and cancer care professionals. 
A first step to meet the patient's needs is the screening of the psychosocial dimensions of cancer as a routine practice in clinical care. The standard application of short clinical tools can be of help in improving the detection of maladjustment and psychosocial or psychological morbidity and referral for care of patients who turn out to be in need of psychological help. The use of some of these instruments, such as the Distress Thermometer or the Edmonton Symptom Assessment System (ESAS), which ask the subject to rate his/her level of symptoms on a visual analogue scale from 0 to 10 and to indicate possible problems or needs, can be helpful for these purposes ${ }^{30}$. However, the literature also suggests that they cannot be used alone to diagnose depression, anxiety, or distress in cancer patients ${ }^{31-33}$. Short or standard tools seem to be more adequate having screening properties enabling them to rule out those who do not have a diagnosis but they lack case-finding properties necessary to confirm clinical caseness ${ }^{34}$. Some other tools such as the Hospital and Anxiety Depression Scale (HADS) and the Brief Symptom Inventory (BSI) have also been shown to be helpful as a practical system to monitor psychological states across the disease trajectory. Again $^{35}$, it has to be said that the screening performance of some of these scales (e.g. the HADS-D) is limited compared with standardised psychiatric diagnostic interviews that, in turn, are limited in not being able to identify other psychosocial dimensions of cancer-related suffering, such as demoralisation, health anxiety, and abnormal illness behaviour ${ }^{36}$.

Screening should be part of the application of the standard of care and clinical practice guidelines, many of which have been developed over the last few years and have been found to be extremely important in helping clinicians provide comprehensive care for cancer patients and their families. The National Comprehensive Cancer Network (NCCN) in the United States has established clinical practice guidelines for the management of distress in oncology that are an example of a specific tool for the routine assessment of psychosocial morbidity and an algorithm for the management of psychological disorders (e.g. adjustment disorders, depression, suicide and suicide risk, and cognitive disorders) in cancer patients. The NCCN screening tool also checks for possible problems in other related areas, including physical, emotional, spiritual, family, and practical problems ${ }^{37}$. The Canadian National Standards for Psychosocial Oncology (www.capo.ca) also include a series of organisational and educational standards of care and algorithms for the management of anxiety and depression in cancer settings in all phases of the cancer trajectory ${ }^{38}$, including prevention and survivorship ${ }^{39,40}$. The Australian clinical practice guidelines for the psychosocial care of adults with cancer (www.nhmrc.gov.au) published by the National Breast Cancer Centre and the National Cancer Control Initiative are a further example of the work done in this respect to improve the psychological care of cancer patients. These comprehensive guidelines, which have been endorsed by several cancer societies, such as the American College of Surgeons $(\mathrm{ACoS})$, the Commission on Cancer $(\mathrm{CoC})^{41}$, and the American Society of Clinical Oncology (ASCO) ${ }^{42}$, as well as other professional societies, including the Association of Oncology Social
Work (AOSW) and the Oncology Nursing Society (ONS) ${ }^{43}$, are gradually transforming the approach to psychosocial care in cancer patients.

Some steps are necessary in order to increase the likelihood that the guidelines are regularly implemented and that distress screening treatment algorithms can be applied ${ }^{44,45}$. With respect to this, it is important that, after the screening phase, a more specific evaluation should follow, including a thorough exploration of psychological and behavioural symptoms; this should include previous behavioural health problems, suicidal thoughts, medication use, reliance on substances, and body image and sexuality concerns. Since outcomes do not improve when patients are screened without an established triage algorithm ${ }^{46,47}$, cancer care professionals must offer triage to suitable referrals for suffering patients according to their psychosocial needs; these include mental health, social work and counselling, and chaplaincy services. Follow-up with the more distressed patients who require regular and timely assessment based on the established criteria of the screening instruments is a further step in care, and all of these steps and related data (e.g. type, source, and severity of the distress; relevant history; any suicidal ideation; and types of recommended interventions, including a plan for further evaluation and by whom) should be documented in the patient's treatment record ${ }^{48}$.

In spite of the dissemination of psychosocial care guidelines, unfortunately it has been reported that, in some areas, such as palliative medicine, healthcare professionals tend to still only partially endorse spiritual and cultural assessment and management and psychosocial assessment and management as important priorities for high-quality services ${ }^{49}$. Therefore, although some signs of improvement are becoming apparent, a great deal of work is still necessary, especially, but not exclusively, in some parts of the world ${ }^{50}$.

\section{Evidence-based psychosocial intervention}

Knowledge about the treatment of psychological problems is mandatory for cancer care clinicians, given the number of studies that have shown the efficacy and effectiveness of psychosocial interventions. Counselling, education, coping and psychological support, and more specific forms of psychotherapy in their different formats (group, individual, and family therapy) and orientation (cognitive-behavioural, supportive-expressive, existential, and psychodynamic) have been developed for cancer patients in order to more specifically intervene in all of the conditions where psychological disorders and maladjustment to cancer and treatment emerge. The choice of intervention is related to several variables, including the clinical psychological condition, the type and phase of illness, and the context as well as the availability of psycho-oncology services with trained professionals, which should be part of multidisciplinary teams ${ }^{51,52}$.

The literature on the efficacy of the several forms of specialised psychotherapeutic interventions and psychosocial rehabilitation in oncology indicates a general benefit in reducing the severity of 
psychiatric symptoms ${ }^{53}$ as well as somatic symptoms (e.g. pain) ${ }^{54}$ and in improving quality of life, wellbeing, return to work $^{55,56}$, illness behaviour, and possibly survival ${ }^{57-59}$. The interventions with the most empirical support for treating distress in cancer patients include supportive-expressive group psychotherapy ${ }^{60}$, cognitive-behavioural $^{61}$ and cognitive-existential therapy ${ }^{62}$, meaning-centred psychotherapy ${ }^{63,64}$, mindfulness, and mindfulness stress reduction programs ${ }^{65-67}$ (see also 68-70). Also, there is a growing body of evidence supporting the use of integrative therapies, especially mind-body therapies, as effective supportive care strategies during cancer treatment, although many practices remain understudied, with insufficient evidence to be definitively recommended or avoided ${ }^{71}$.

Psychopharmacological intervention has also been shown to be efficacious in several psychological disorders, where the use of some medications acting on the serotonergic and noradrenergic system (e.g. Selective serotonin reuptake inhibitors and Selective noradrenergic and serotonin reuptake inhibitors) have been shown to help in treating depression and anxiety and cancer-related symptoms, such as hot flashes and pain ${ }^{72,73}$. With respect to this, it is important for clinicians, usually psychiatrists but also oncologists and primary care physicians, to have proper training on the use of the drugs, their side effects, and their interactions with other cancer treatment in oncology $y^{74,75}$.

\section{Conclusions}

Cancer and its treatment have a tremendous psychological and psychosocial impact on both patients and their families and are accompanied by a series of dramatic changes that involve the physical, emotional, spiritual, interpersonal, and social dimensions of the person with cancer. Acknowledging that a high percentage of cancer patients suffer from emotional symptoms (e.g. health anxiety, irritable mood, and demoralisation) or psychopathological conditions (e.g. major depression and posttraumatic stress disorder) is extremely important for cancer care professionals to provide integrated and comprehensive care in oncology. There is now, in fact, scientific evidence of the benefits of providing psychosocial cancer care to patients and families as part of standard care in reducing distress and psychosocial morbidity associated with cancer and in fostering a better quality of life during and after treatment, and eventually increased survival ${ }^{76}$.

The significant advances in research in the area of psychooncology have favoured the development, implementation, and dissemination of psychosocial guidelines and evidence-based treatments for several co-morbid psychiatric disorders in cancer, such as depression ${ }^{77}$ and anxiety ${ }^{78}$. However, more steps should be taken in psychosocial approaches to cancer, both in the hospital and in the community ${ }^{79}$. Besides specific cancer care fields, such as oncology and palliative care, primary care should be particularly considered in its role of continuous, coordinated, and comprehensive care for individuals and families, including psychosocial care, in prevention and diagnosis, in shared followup and survivorship care, and in end-of-life care ${ }^{80}$.

\section{Competing interests}

The authors declare that they have no competing interests.

\section{Grant information}

Luigi Grassi acknowledges the support of the University of Ferrara research grant FAR-2016. David Spiegel acknowledges the support of NCI U01 CA 197282 and the Stanford Cancer Institute, an NCIdesignated Comprehensive Cancer Center.

The funders had no role in study design, data collection and analysis, decision to publish, or preparation of the manuscript.
1. World Health Organization: Cancer. WHO, Geneva, 2017. Reference Source

2. Grassi L, Biancosino B, Marmai L, et al.: Psychological factors affecting oncology conditions. Adv Psychosom Med. 2007; 28: 57-71. PubMed Abstract | Publisher Full Text

3. Caruso R, Nanni MG, Riba MB, et al:: The burden of psychosocial morbidity related to cancer: patient and family issues. Int Rev Psychiatry. 2017; 29(5) 389-402.

PubMed Abstract | Publisher Full Text

4. $\quad \mathrm{F}$ Nipp RD, El-Jawahri A, Fishbein JN, et al:: The relationship between coping strategies, quality of life, and mood in patients with incurable cancer. Cancer. 2016; 122(13): 2110-6.

PubMed Abstract | Publisher Full Text | Free Full Text | F1000 Recommendation

5. $\quad \mathrm{F}$ McFarland DC, Holland JC: The management of psychological issues in oncology. Clin Adv Hematol Oncol. 2016; 14(12): 999-1009. PubMed Abstract | F1000 Recommendation

6. Bultz BD, Carlson LE: Emotional distress: the sixth vital sign--future directions in cancer care. Psychooncology. 2006; 15(2): 93-5. PubMed Abstract | Publisher Full Text

7. Bultz BD, Johansen C: Screening for distress, the 6th vital sign: where are we, and where are we going? Psychooncology. 2011; 20(6): 569-71. PubMed Abstract | Publisher Full Text
8. Travado L, Breitbart W, Grassi L, et al.: 2015 President's Plenary International Psycho-oncology Society: psychosocial care as a human rights issuechallenges and opportunities. Psychooncology. 2017; 26(4): 563-9. PubMed Abstract | Publisher Full Text | Free Full Text

9. National Comprehensive Cancer Network (NCCN): Distress management. Version 2.2017. NCCN, 2017. Reference Source

10. Mitchell AJ, Chan M, Bhatti $\mathrm{H}$, et al:: Prevalence of depression, anxiety, and adjustment disorder in oncological, haematological, and palliative-care settings: a meta-analysis of 94 interview-based studies. Lancet Oncol. 2011; 12(2): 160-74.

PubMed Abstract | Publisher Full Text

11. Cordova MJ, Riba MB, Spiegel D: Post-traumatic stress disorder and cancer. Lancet Psychiatry. 2017; 4(4): 330-8. PubMed Abstract | Publisher Full Text | Free Full Text

12. Caruso R, Nanni MG, Riba M, et al:: Depressive spectrum disorders in cancer: prevalence, risk factors and screening for depression: a critical review. Acta Oncol. 2017; 56(2): 146-55. PubMed Abstract | Publisher Full Text

13. Caruso R, GiuliaNanni M, Riba MB, et al.: Depressive Spectrum Disorders in Cancer: Diagnostic Issues and Intervention. A Critical Review. Curr Psychiatry Rep. 2017; 19(6): 33. PubMed Abstract | Publisher Full Text | Free Full Text 
14. Spiegel $D$, Riba MB: Managing anxiety and depression during treatment. Breast J. 2015; 21(1): 97-103.

PubMed Abstract | Publisher Full Text

15. Roth AJ, Carter J, Seidel B, et al:: Sexual Problems After Cancer. In: Holland JC, Breitbart WS, Jacobsen PB, Loscalzo MJ, McCorkle R, Butow PN, editors. PsychoOncology: Oxford University Press; 2015; 220-224.

Publisher Full Text

16. F Tang PL, Wang HH, Chou FH: A Systematic Review and Meta-Analysis of Demoralization and Depression in Patients With Cancer. Psychosomatics. 2015; 56(6): 634-43.

PubMed Abstract | Publisher Full Text | F1000 Recommendation

17. F Robinson S, Kissane DW, Brooker J, et al.: A systematic review of the demoralization syndrome in individuals with progressive disease and cancer: a decade of research. J Pain Symptom Manage. 2015; 49(3): 595-610. PubMed Abstract | Publisher Full Text | F1000 Recommendation

18. Grassi L, Nanni MG: Demoralization syndrome: New insights in psychosocial cancer care. Cancer. 2016; 122(14): 2130-3.

PubMed Abstract | Publisher Full Text

19. Grassi L, Caruso R, Nanni MG: Somatization and somatic symptom presentation in cancer: a neglected area. Int Rev Psychiatry. 2013; 25(1): 41-51. PubMed Abstract | Publisher Full Text

20. Forsythe LP, Kent EE, Weaver KE, et al:: Receipt of psychosocial care among cancer survivors in the United States. J Clin Oncol. 2013; 31(16): 1961-9. PubMed Abstract | Publisher Full Text | Free Full Text

21. F Sarkar S, Sautier L, Schilling G, et al:: Anxiety and fear of cancer recurrence and its association with supportive care needs and health-care service utilization in cancer patients. J Cancer Surviv. 2015; 9(4): 567-75. PubMed Abstract | Publisher Full Text | F1000 Recommendation

22. F Vehling S, Mehnert A, Hartmann M, et al.: Anxiety and depression in long term testicular germ cell tumor survivors. Gen Hosp Psychiatry. 2016; 38: 21-5. PubMed Abstract | Publisher Full Text | F1000 Recommendation

23. F Stanton AL, Rowland JH, Ganz PA: Life after diagnosis and treatment of cancer in adulthood: contributions from psychosocial oncology research. $A m$ Psychol. 2015; 70(2): 159-74.

PubMed Abstract | Publisher Full Text | F1000 Recommendation

24. Stanton AL: What happens now? Psychosocial care for cancer survivors after medical treatment completion. J Clin Oncol. 2012; 30(11): 1215-20. PubMed Abstract | Publisher Full Text

25. F Barnett M, McDonnell G, DeRosa A, et al:: Psychosocial outcomes and interventions among cancer survivors diagnosed during adolescence and young adulthood (AYA): a systematic review. J Cancer Surviv. 2016; 10(5): 814-31.

PubMed Abstract | Publisher Full Text | Free Full Text | F1000 Recommendation

26. Aaronson NK, Mattioli V, Minton O, et al.: Beyond treatment - Psychosocial and behavioural issues in cancer survivorship research and practice. EJC Suppl. 2014; 12(1): 54-64

PubMed Abstract | Publisher Full Text | Free Full Text

27. Giese-Davis J, Collie K, Rancourt KM, et al.: Decrease in depression symptoms is associated with longer survival in patients with metastatic breast cancer: a secondary analysis. J Clin Oncol. 2011; 29(4): 413-20. PubMed Abstract | Publisher Full Text | Free Full Text

28. Anguiano L, Mayer DK, Piven ML, et al: : A literature review of suicide in cancer patients. Cancer Nurs. 2012; 35(4): E14-26.

PubMed Abstract | Publisher Full Text

29. Kissane DW: Unrecognised and untreated depression in cancer care. Lance Psychiatry 2014; 1(5): 320-1.

PubMed Abstract | Publisher Full Text

30. Donovan KA, Grassi L, McGinty HL, et al:: Validation of the distress thermometer worldwide: state of the science. Psychooncology. 2014; 23(3): 241-50. PubMed Abstract | Publisher Full Text

31. Mitchell AJ: Short screening tools for cancer-related distress: a review and diagnostic validity meta-analysis. J Natl Compr Canc Netw. 2010; 8(4): 487-94. PubMed Abstract | Publisher Full Text

32. Mitchell AJ: Pooled results from $\mathbf{3 8}$ analyses of the accuracy of distress thermometer and other ultra-short methods of detecting cancer-related mood disorders. J Clin Oncol. 2007; 25(29): 4670-81.

PubMed Abstract | Publisher Full Text

33. Vodermaier A, Linden W, Siu C: Screening for emotional distress in cancer patients: a systematic review of assessment instruments. J Nat/ Cancer Inst. 2009; 101(21): 1464-88

PubMed Abstract | Publisher Full Text | Free Full Text

34. Mitchell AJ, Meader N, Davies E, et al:: Meta-analysis of screening and case finding tools for depression in cancer: evidence based recommendations for clinical practice on behalf of the Depression in Cancer Care consensus group. $J$ Affect Disord. 2012; 140(2): 149-60.

PubMed Abstract | Publisher Full Tex

35. Hartung TJ, Friedrich M, Johansen C, et al:: The Hospital Anxiety and Depression Scale (HADS) and the 9-item Patient Health Questionnaire (PHQ-9) as screening instruments for depression in patients with cancer. Cancer. 2017; 123(21): $4236-4243$

PubMed Abstract | Publisher Full Text
36. Grassi L, Sabato S, Rossi E, et al.: Use of the diagnostic criteria for psychosomatic research in oncology. Psychother Psychosom. 2005; 74(2): $100-7$.

PubMed Abstract | Publisher Full Text

37. National Comprehensive Cancer Network: NCCN Clinical Practice Guidelines in Oncology. Distress Management. Version 2. ๑ National Comprehensive Cancer Network, Fort Washington, PA USA. 2016

38. Howell D, Keshavarz H, Esplen MJ, et al.: A Pan Canadian Practice Guideline: Screening, Assessment and Care of Psychosocial Distress, Depression, and Anxiety in Adults with Cancer. Toronto: Canadian Partnership Against Cancer and the Canadian Association of Psychosocial Oncology, 2015.

39. Howell D, Currie S, Mayo S, et al.: A Pan-Canadian Clinical Practice Guideline: Assessment of Psychosocial Health Care Needs of the Adult Cancer Patient. Toronto: Canadian Partnership Against Cancer (Cancer Journey Action Group) and the Canadian Association of Psychosocial Oncology, 2009 Reference Source

40. Howell D, Hack TF, Oliver TK, et al: A Pan-Canadian Practice Guideline PanCanadian Guidance on Organization and Structure of Survivorship Services and Psychosocial-Supportive Care Best Practices for Adult Cancer Survivors. Toronto: Canadian Partnership Against Cancer (Cancer Journey Action Group) and the Canadian Association of Psychosocial Oncology, 2011.

41. Wagner LI, Spiegel D, Pearman T: Using the science of psychosocial care to implement the new american college of surgeons commission on cance distress screening standard. J Natl Compr Canc Netw. 2013; 11(2): 214-21. PubMed Abstract | Publisher Full Text

42. Andersen BL, DeRubeis RJ, Berman BS, et al:: Screening, assessment, and care of anxiety and depressive symptoms in adults with cancer: an American Society of Clinical Oncology guideline adaptation. J Clin Oncol. 2014; 32(15): 1605-19.

PubMed Abstract | Publisher Full Text | Free Full Text

43. Pirl WF, Fann JR, Greer JA, et al:: Recommendations for the implementation of distress screening programs in cancer centers: report from the American Psychosocial Oncology Society (APOS), Association of Oncology Social Work (AOSW), and Oncology Nursing Society (ONS) joint task force. Cancer. 2014; 120(19): 2946-54

PubMed Abstract | Publisher Full Text

44. Clark PG, Bolte S, Buzaglo J, et al:: From distress guidelines to developing models of psychosocial care: current best practices. J Psychosoc Oncol. 2012; 30(6): 694-714

PubMed Abstract | Publisher Full Text

45. F Shaw JM, Price MA, Clayton JM, et al:: Developing a clinical pathway for the identification and management of anxiety and depression in adult cance patients: an online Delphi consensus process. Support Care Cancer. 2016. 24(1): 33-41.

PubMed Abstract | Publisher Full Text | F1000 Recommendation

46. Carlson LE, Waller A, Mitchell AJ: Screening for distress and unmet needs in patients with cancer: review and recommendations. J Clin Oncol. 2012; 30(11): $1160-77$

PubMed Abstract | Publisher Full Text

47. Howell D, Hack TF, Green E, et al.: Cancer distress screening data: translating knowledge into clinical action for a quality response. Palliat Support Care. 2014; 12(1): 39-51.

PubMed Abstract | Publisher Full Text

48. F Lazenby M, Tan H, Pasacreta N, et al:: The five steps of comprehensive psychosocial distress screening. Curr Oncol Rep. 2015; 17(5): 447. PubMed Abstract | Publisher Full Text | Free Full Text | F1000 Recommendation

49. F Bickel KE, McNiff K, Buss MK, et al.: Defining High-Quality Palliative Care in Oncology Practice: An American Society of Clinical Oncology/American Academy of Hospice and Palliative Medicine Guidance Statement. J Oncol Pract. 2016; 12(9): e828-38.

PubMed Abstract | Publisher Full Text | F1000 Recommendation

50. Grassi L, Fujisawa D, Odyio P, et al:: Disparities in psychosocial cancer care: a report from the International Federation of Psycho-oncology Societies. Psychooncology. 2016; 25(10): 1127-36.

PubMed Abstract| Publisher Full Text

51. Tamagawa R, Garland S, Vaska M, et al:: Who benefits from psychosocial interventions in oncology? A systematic review of psychological moderators of treatment outcome. J Behav Med. 2012; 35(6): 658-73.

PubMed Abstract | Publisher Full Tex

52. Grassi L, Caruso R, Nanni MG: Psycho-oncology and optimal standards of cancer care: developments, multidisciplinary team approach and international guidelines. In Wise TN, Biondi M, Costantini A. (Eds.), Psycho-Oncology. American Psychiatric Publishing Press, Arlington, VA, 2013; 315-339.

53. Zainal NZ, Booth S, Huppert FA: The efficacy of mindfulness-based stress reduction on mental health of breast cancer patients: a meta-analysis. Psychooncology. 2013; 22(7): 1457-65. PubMed Abstract | Publisher Full Tex

54. Johannsen M, Farver I, Beck N, et al.: The efficacy of psychosocial intervention for pain in breast cancer patients and survivors: a systematic review and meta-analysis. Breast Cancer Res Treat. 2013; 138(3): 675-90. PubMed Abstract | Publisher Full Text

55. F Hunter EG, Gibson RW, Arbesman M, et al:: Systematic Review of 
Occupational Therapy and Adult Cancer Rehabilitation: Part 1. Impact of Physical Activity and Symptom Management Interventions. Am J Occup Ther. 2017; 71(2): 7102100030p1-7102100030p11.

PubMed Abstract | Publisher Full Text | F1000 Recommendation

56. F Hunter EG, Gibson RW, Arbesman M, et al: Systematic Review of Occupational Therapy and Adult Cancer Rehabilitation: Part 2. Impact of Multidisciplinary Rehabilitation and Psychosocial, Sexuality, and Return-toWork Interventions. Am J Occup Ther. 2017; 71(2): 7102100040p1-7102100040p8. PubMed Abstract | Publisher Full Text | F1000 Recommendation

57. Barrera I, Spiegel D: Review of psychotherapeutic interventions on depression in cancer patients and their impact on disease progression. Int Rev Psychiatry. 2014; 26(1): 31-43

PubMed Abstract | Publisher Full Text

58. Spiegel D: Mind matters in cancer survival. Psychooncology. 2012; 21(6): 588-93. PubMed Abstract | Publisher Full Text | Free Full Text

59. Galway K, Black A, Cantwell M, et al:: Psychosocial interventions to improve quality of life and emotional wellbeing for recently diagnosed cancer patients. Cochrane Database Syst Rev. 2012; 11: CD007064.

PubMed Abstract | Publisher Full Text

60. Classen CC, Kraemer HC, Blasey C, et al:: Supportive-expressive group therapy for primary breast cancer patients: a randomized prospective multicenter trial. Psychooncology. 2008; 17(5): 438-47. PubMed Abstract | Publisher Full Text | Free Full Text

61. F Johnson JA, Rash JA, Campbell TS, et al.: A systematic review and metaanalysis of randomized controlled trials of cognitive behavior therapy for insomnia (CBT-I) in cancer survivors. Sleep Med Rev. 2016; 27: 20-8. PubMed Abstract | Publisher Full Text | F1000 Recommendation

62. Kissane DW, Bloch S, Smith GC, et al.: Cognitive-existential group psychotherapy for women with primary breast cancer: a randomised controlled trial. Psychooncology. 2003; 12(6): 532-46. PubMed Abstract | Publisher Full Text

63. F Breitbart W, Rosenfeld B, Pessin H, et al:: Meaning-centered group psychotherapy: an effective intervention for improving psychological wellbeing in patients with advanced cancer. J Clin Oncol. 2015; 33(7): 749-54. PubMed Abstract | Publisher Full Text | Free Full Text | F1000 Recommendation

64. F van der Spek N, Vos J, van Uden-Kraan CF, et al.: Efficacy of meaningcentered group psychotherapy for cancer survivors: a randomized controlled trial. Psychol Med. 2017; 47(11): 1990-2001. PubMed Abstract | Publisher Full Text | Free Full Text | F1000 Recommendation

65. F Rouleau CR, Garland SN, Carlson LE: The impact of mindfulness-based interventions on symptom burden, positive psychological outcomes, and biomarkers in cancer patients. Cancer Manag Res. 2015; 7: 121-31. PubMed Abstract | Publisher Full Text | Free Full Text | F1000 Recommendation

66. F Carlson LE: Mindfulness-based interventions for coping with cancer. Ann NY Acad Sci. 2016; 1373(1): 5-12.

PubMed Abstract | Publisher Full Text | F1000 Recommendation
67. Piet $\mathrm{J}$, Würtzen $\mathrm{H}$, Zachariae R: The effect of mindfulness-based therapy on symptoms of anxiety and depression in adult cancer patients and survivors: a systematic review and meta-analysis. J Consult Clin Psychol. 2012; 80(6): 1007-20. PubMed Abstract | Publisher Full Text

68. LeMay K, Wilson KG: Treatment of existential distress in life threatening illness: a review of manualized interventions. Clin Psychol Rev. 2008; 28(3): 472-93. PubMed Abstract | Publisher Full Text

69. Watson M, Kissane DW: Handbook of Psychotherapy in Cancer Care. Chichester, UK: John Wiley \& Sons, Ltd; 2011 Reference Source

70. F Okuyama T, Akechi T, Mackenzie L, et al:: Psychotherapy for depression among advanced, incurable cancer patients: A systematic review and metaanalysis. Cancer Treat Rev. 2017; 56: 16-27.

PubMed Abstract | Publisher Full Text | F1000 Recommendation

71. F Greenlee H, DuPont-Reyes MJ, Balneaves LG, et al:: Clinical practice guidelines on the evidence-based use of integrative therapies during and after breast cancer treatment. CA Cancer J Clin. 2017; 67(3): 194-232. PubMed Abstract | Publisher Full Text | F1000 Recommendation

72. Caruso R, Grassi L, Nanni MG, et al.: Psychopharmacology in psycho-oncology. Curr Psychiatry Rep. 2013; 15(9): 393. PubMed Abstract | Publisher Full Text

73. Grassi L, Caruso R, Hammelef K, et al.: Efficacy and safety of pharmacotherapy in cancer-related psychiatric disorders across the trajectory of cancer care: a review. Int Rev Psychiatry. 2014; 26(1): 44-62. PubMed Abstract | Publisher Full Text

74. Grassi L, Caruso R, Rodin G, et al:: The use of antidepressants in cancer care: a review and practical cila tips for oncologists. Annals of Oncology. (in press).

75. Grassi L, Riba M, (Eds.): Psychopharmacology in oncology and palliative care. Springer, Berlin/New York, 2014. Publisher Full Text

76. Bultz BD, Cummings GG, Grassi L, et al.: 2013 President's Plenary International Psycho-oncology Society: embracing the IPOS standards as a means of enhancing comprehensive cancer care. Psychooncology. 2014; 23(9): 1073-8. PubMed Abstract | Publisher Full Text

77. Li M, Fitzgerald P, Rodin G: Evidence-based treatment of depression in patients with cancer. J Clin Oncol. 2012; 30(11): 1187-96. PubMed Abstract | Publisher Full Text

78. Traeger L, Greer JA, Fernandez-Robles C, et al: Evidence-based treatment of anxiety in patients with cancer. J Clin Oncol. 2012; 30(11): 1197-205. PubMed Abstract | Publisher Full Text

79. F Andersen BL, Dorfman CS: Evidence-based psychosocial treatment in the community: considerations for dissemination and implementation. Psychooncology. 2016; 25(5): 482-90.

PubMed Abstract | Publisher Full Text | Free Full Text | F1000 Recommendation

80. Rubin G, Berendsen A, Crawford SM, et al:: The expanding role of primary care in cancer control. Lancet Oncol. 2015; 16(12): 1231-72. PubMed Abstract | Publisher Full Text 


\section{Open Peer Review}

\section{Current Peer Review Status:}

\section{Editorial Note on the Review Process}

Faculty Reviews are review articles written by the prestigious Members of Faculty Opinions. The articles are commissioned and peer reviewed before publication to ensure that the final, published version is comprehensive and accessible. The reviewers who approved the final version are listed with their names and affiliations.

\section{The reviewers who approved this article are:}

\section{Version 1}

\section{Kristine Donovan}

Moffitt Cancer Center, Tampa, Florida, USA

Competing Interests: No competing interests were disclosed.

\section{Linda E. Carlson}

University of Calgary, Calgary, Alberta, Canada

Competing Interests: No competing interests were disclosed.

\section{Anja Mehnert-Theuerkauf}

Department of Medical Psychology and Medical Sociology, University Medical Center Leipzig, Leipzig, Germany

Competing Interests: No competing interests were disclosed.

The benefits of publishing with F1000Research:

- Your article is published within days, with no editorial bias

- You can publish traditional articles, null/negative results, case reports, data notes and more

- The peer review process is transparent and collaborative

- Your article is indexed in PubMed after passing peer review

- Dedicated customer support at every stage

For pre-submission enquiries, contact research@f1000.com 